\title{
Pengaruh Penerapan Good Corporate Governance, Total Asset Turn Over dan Kepemilikan Institusional Terhadap Kinerja Keuangan Perusahaan
}

\author{
Dita Silfana Dewi ${ }^{1 *}$, Arik Susbiyani², Achmad Syahfrudin ${ }^{3}$ \\ ${ }^{123}$ Universitas Muhammadiyah Jember
}

\author{
A R T I C L E I N F O \\ Article history: \\ Received 19 August 2019 \\ Received in revised form \\ 16 September 2019 \\ Accepted 15 October 2019 \\ Available online 30 \\ November 2019 \\ Kata Kunci: \\ Sistem Gaji Good Corporate \\ Governance, Total Asset \\ Turn Over, Kepemilikan \\ Institusional, dan Kinerja \\ Keuangan \\ Keywords: \\ Good Corporate Governance, \\ Total Asset Turn Over \\ Institutional Ownership, and \\ Financial Performance
}

\begin{abstract}
A B S T R A K
Penelitian ini bertujuan untuk menganalisis Pengaruh Penerapan Good Corporate Governance, Total Asset Turn Over dan Kepemilikan Institusional Terhadap Kinerja Keuangan Perusahaan (Studi pada Perusahaan Manufaktur yang Terdaftar di Bursa Efek Indonesia Periode 2015-2017). Penelitian ini dilakukan dengan menggunakan metode purposive sampling. Sampel yang digunakan dalam penelitian ini adalah perusahaan yang menjadi peserta dalam Corporate Governance Perception index (CGPI) periode 2015-2017 yang dilakukan oleh (The Indonesian Institute for Corporate Governance (IICG) berupa skor pemeringkatan Corporate Governance Perception Index (CGPI). Metode analisis data yang digunakan adalah metode analisis regresi linier berganda. Uji hipotesis yang digunakan adalah uji $\mathrm{t}$, uji $\mathrm{F}$ dan koefisien determinasi. Hasil penelitian menunjukkan bahwa Good Corporate Governance dan Kepemilikan Institusional berpengaruh terhadap Kinerja Keuangan Perusahaan, sedangkan Total Asset Turn Over tidak berpengaruh terhadap Kinerja Keuangan Perusahaan.
\end{abstract}

\section{A B S T R A C T}

Implementation of Good Corporate Governance, Total Asset Turnover and Institutional Ownership of the Company's Financial Performance (Study of Manufacturing Companies Listed on the Indonesia Stock Exchange for the 2015-2017 Period). This research was conducted using a purposive sampling method. The sample used in this study is a company that participates in the Corporate Governance Perception Index (CGPI) for the period 2015-2017 conducted by (IICG) which involves a rating score of the Corporate Governance Perception Index (CGPI). the method used is multiple linear regression analysis. The hypothesis test used is the $t$ test, $F$ test and coefficient of determination. The results of the study show that Good Corporate Governance and Institutional Ownership link the Company's Financial Performance, while the Total Asset Turnover is not related to the Company's Financial Performance

\footnotetext{
Corresponding author.

E-mail addresses: Ditasilfana@gmail.com (Dita Silfana Dewi)
} 


\section{Pendahuluan}

Perusahaan yang go public adalah perusahan-perusahaan besar yang terdaftar di Bursa Efek Indonesia yang menjanjikan laba yang tinggi untuk menarik para investor salah satunya adalah perusahaan manufaktur. Perusahaan besar yang go public seharusnya memiliki tata kelola perusahaan yang baik atau yang dikenal dengan Good Corporate Governance. Namun kondisi yang dihadapi perusahaan-perusahaan publik di Indonesia masih lemah dan kurang dalam mengelola perusahaannya. Hal tersebut terlihat dari lemahnya standar pengungkapan dan transparasi, standar akuntansi dan regulasi serta pertanggung jawaban terhadap para investor. Penerapan dan pengelolaan Good Corporate Governance merupakan sebuah konsep yang menekankan pentingnya hak pemegang saham untuk memperoleh informasi dengan benar, akurat dan tepat waktu dan transparan (Freshilia dan Rusiti, 2014).

Kesulitan moneter di tahun ini 2015, kurs rupiah melemah sampai menembus Rp.13,851 terhadap dolar Amerika, walaupun Bank Indonesia pada tanggal 18 Agustus 2015 dalam siaran persnya menyatakan nilai tukar rupiah mengalami depresiaisi, rata-rata melemah 2,47\% ke level Rp.13,131 per dolar Amerika terutama dipengaruhi oleh sentiment eksternal. Pada triwulan ke II 2015, menurut Bank Indonesia rupiah dicatat pelemahan cukup dalam (overshoot) dan telah di bawah nilai fundamental (undervalued). Menurut Bank Indonesia dalam siaran persnya menyatakan Bank Central Cina melakukan devaluasi Yuan dan merubah mekanisme penentuan nilai tukar Yuan menjadi lebih market driven, yang juga memberikan dampak tambahan risiko tekanan nilai tukar negara-negara mitra dengan Cina, termasuk Indonesia. (detikfinance, 2015).

Menurut Darwis (2009), secara teoritis praktik good Good Corporate Governance dapat meningkatkan kinerja perusahaan. Namun hal ini berbanding terbalik dengan fenomena Perusahaan manufaktur merupakan perusahaan bisnis di sektor riil yang sangat rentan dan sensitif bila terjadi inflasi. Dengan terjadinya fluktuasi kurs rupiah yang cukup tajam dan ketidakstabilan kurs rupiah dapat menyebabkan kemampuan daya beli masyarakat akan berkurang, bisnis sektor rill adalah bisnis yang bersentuhan langsung dengan permintaan pasar dan kemampuan daya beli lokal. Hal ini dibuktikan dengan beberapa perusahaan manufaktur yang cukup besar seperti perusahaan industri mobil ford menutup usahanya di akhir tahun 2015 disebabkan rendahnya permintaan pasar akibat dari ketidakmampuan masyarakat lokal (Indonesia) membeli produk mereka sehingga kinerja keuangan perusahaan ford sangat buruk.

\section{Metode}

Jenis data yang digunakan dalam penelitian ini adalah data sekunder. Menurut Indriantoro dan Supomo (2014:147) data sekunder merupakan sumber data penelitian yang diperoleh peneliti secara tidak langsung melalui media perantara (diperoleh dan dicatat oleh pihak lain). Data sekunder dalam laporan ini berupa data perusahaan yang menjadi peserta Corporate Governance Perception Index (CGPI) periode 2015-2017.Data berasal dari laporan keuangan tahunan perusahaan yang menjadi peserta dalam Corporate Governance Perception index (CGPI) periode 2013-2017 yang merupakan data tertulis yang berhubungan dengan objek penelitian yang diterbitkan oleh perusahaan yang bersangkutan. Adapun sumber data yang digunakan dalam penelitian ini adalah data sekunder, yaitu sumber penelitian yang diperoleh secara tidak langsung melalui media perantara. Pengumpulan data dilakukan dengan metode dokumentasi yang dilakukan dengan mengumpulkan data sekunder berupa laporan keuangan yang telah dipublikasikan oleh perusahaan yang menjadi peserta dalam Corporate Governance Perception index (CGPI) periode 2015-2017. Data sekunder dapat diperoleh dengan mengakses website dan situs-situs yang menyediakan informasi sehubungan dengan masalah dalam penelitian. Data diperoleh dari situs resmi yang dimiliki oleh Bursa Efek Indonesia yaitu www.idx.co.id, jurnal-jurnal, penelitian-penelitian terdahulu, dan menghubungi langsung pihak IICG melalui email vivi@iicg.org

ROA merupakan kemampuan perusahaan dalam menghasilkan laba dari asset perusahaan itu sendiri dengan menggunakan skala rasio. Formulasinya adalah sebagai berikut (Brigham dan Houston, 2010):

$$
\mathrm{ROA}=\frac{\text { Net Income }}{\text { Total Asset }}
$$

Good Corporate Governance merupakan tata kelola perusahaan yang menjelaskan hubungan antara berbagai partisipan dalam perusahaan yang menentukan arah kinerja perusahaan. Good Corporate Governance merupakan mekanisme pengendalian untuk mengatur dan mengelola perusahaan dengan maksud untuk meningkatkan kemakmuran dan akuntabilitas perusahaan, yang tujuan akhirnya untuk 
mewujudkan shareholders value. Good Corporate Governance diukur menggunakan skor Corporate Governance Perception Index (CGPI) yang dilakukan oleh The Indonesian Institute of Corporate Governance (Gumanti, 2011), sehingga:

$$
\mathrm{CG}=\text { Indeks CGPI }
$$

Rasio aktivitas dihitung dengan menggunakan TATO (Total Asset Turn Offer). TATO (Total Asset Turn Over) adalah rasio yang mengukur tingkat efisiensi penggunaan keseluruhan aktiva perusahaan dalam menghasilkan volume penjualan tertentu. Menurut Kasmir (2013:135) TATO dapat dirumuskan sebagai berikut:

$$
\text { TATO }=\frac{\text { Penjualan }}{\text { Total Aktiva }} \times 100 \%
$$

Kepemilikan institusional diukur dengan melihat proporsi saham yang dimiliki institusi seperti institusi asing, pemerintah, dan perusahaan swasta. rumus yang digunakan untuk menghitung kepemilikan institusional dalam Sabrinna (2010) adalah sebagai berikut:

$$
\frac{\mathrm{KI}=\text { Jumlah saham yang dimiliki oleh Institusi }}{\text { Jumlah saham yang beredar }}
$$

Metode analisis data yang digunakan dalam penelitian ini adalah metode analisis statistik dengan persamaan regresi linier berganda dengan menggunakan aplikasi SPSS.

\section{Hasil dan pembahasan}

Gambaran Umum

Penelitian ini menggunakan data sekunder berupa laporan tahunan yang diperoleh dari website resmi Bursa Efek Indonesia (www.idx.co.id), serta website resmi perusahaan-perusahaan yang menjadi objek penelitian. Populasi yang digunakan dalam penelitian ini adalah Perusahaan yang menjadi peserta Corporate Governance Perception Index (CGPI) tahun 2015-2017. Pemilihan sampel dalam penelitian ini menggunakan metode purposive sampling. Berikut ini adalah data pemilihan sampel berdasarkan kriteriakriteria yang telah ditetapkan:

Tabel 1 Kriteria Pemilihan Sampel Penelitian

\begin{tabular}{llc}
\hline No. & Kriteria Sampel & Jumlah \\
\hline 1 & $\begin{array}{l}\text { Perusahaan yang menjadi peserta Corporate Governance Perception Index } \\
\text { (CGPI) tahun 2015-2017. }\end{array}$ & 30 \\
2 & $\begin{array}{l}\text { Perusahaan yang terdaftar di Bursa Efek Indonesia dan menerbitkan laporan } \\
\text { keuangan tahunan (annual report) untuk periode yang berakhir pada }\end{array}$ & \\
& $\begin{array}{l}\text { Desember selama periode 2015-2017. } \\
\text { Perusahaan yang mencantumkan jumlah saham yang dimiliki oleh direksi } \\
\text { dan komisaris, serta jumlah saham yang dimiliki oleh institusi }\end{array}$ & (18) \\
\hline Jumlah sampel perusahaan & 10 \\
\hline Jumlah sampel selama tahun penelitian (2015-2017) (10*3) & Sumber: Lampiran 1 (Data Diolah, 2019)
\end{tabular}

Jumlah perusahaan yang menjadi peserta Corporate Governance Perception Index (CGPI) tahun 2015-2017 berjumlah 30 data pelitian dari Bursa Efek Indonesia (BEI). Berdasarkan data kualifikasi diatas maka ada 10 perusahaan yang bisa dijadikan sampel penelitian selama periode 2015-2017. Dengan jumlah sampel 10 perusahaan untuk 3 tahun pengamatan.

\section{Deskripsi hasil \\ Statistik Deskriptif}

Setelah menganalisis data ke 30 data penelitian, tahap selanjutnya adalah mengolah data statistik deskriptif variabel penelitian. Hasil pengolahan data statistik deskriptif variabel penelitian tampak pada Tabel 2. berikut ini 
Tabel 2 Hasil Statistik Deskriptif

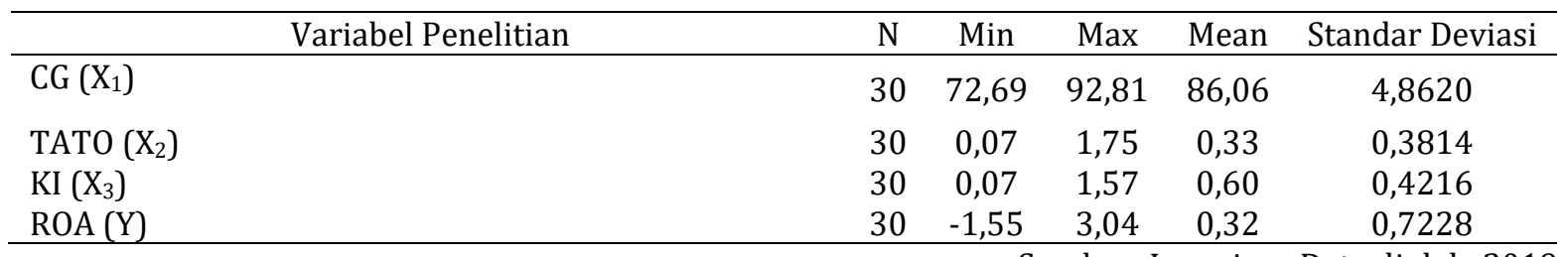

Berdasarkan hasil analisis pada Tabel 2 dapat diketahui bahwa untuk variabel CG menunjukkan nilai rata-rata (mean) sebesar 86,06. Nilai terendah variabel CG sebesar 72,69 dan nilai tertinggi 92,81. Standar deviasi sebesar 4,8260. Hal ini berarti nilai standar deviasi yang mendekati nilai rata-rata (mean) dan ukuran penyebaran data yang semakin kecil.

Berdasarkan hasil analisis pada Tabel 4.1 dapat diketahui bahwa untuk variabel TATO menunjukkan nilai rata-rata (mean) sebesar 0,33. Nilai terendah variabel TAT0 sebesar 0,07 dan nilai tertinggi 1,75. Standar deviasi sebesar 0,3814. Hal ini berarti nilai standar deviasi yang mendekati nilai rata-rata (mean) dan ukuran penyebaran data yang semakin kecil.

Berdasarkan hasil analisis pada Tabel 4.1 dapat diketahui bahwa untuk variabel KI menunjukkan nilai rata-rata (mean) sebesar 0,60. Nilai terendah variabel KI sebesar 0,07 dan nilai tertinggi 1,57. Standar deviasi sebesar 0,4216. Hal ini berarti nilai standar deviasi yang mendekati nilai rata-rata (mean) dan ukuran penyebaran data yang semakin kecil.

Berdasarkan hasil analisis pada Tabel 4.1 dapat diketahui bahwa untuk variabel ROAmenunjukkan nilai rata-rata (mean) sebesar 0,322. Nilai terendah variabel ROAsebesar $-1,55$ dan nilai tertinggi 3,04. Standar deviasi sebesar 0,7228 . Hal ini berarti nilai standar deviasi yang mendekati nilai rata-rata (mean) dan ukuran penyebaran data yang semakin kecil

\section{Analisis Regresi Linier Berganda}

Menurut Dewi (2016) uji persamaan regresi digunakan untuk menguji keakuratan model dan untuk memberikan gambaran yang jelas mengenai pengaruh variabel-variabel independen yang digunakan terhadap variabel dependen. Hasil analisis regresi linier berganda terhadap hipotesis peneitian dapat dilihat pada Tabel 3 sebagai berikut:

Tabel 3 Hasil Analisis Regresi Linier Berganda

\begin{tabular}{lcll}
\hline Variabel & Koefisien Regresi & Sig. & Keterangan \\
\hline Konstanta & 0,200 & - & - \\
CG $\left(\mathrm{X}_{1}\right)$ & 0,439 & 0,006 & Signifikan \\
TATO $\left(\mathrm{X}_{2}\right)$ & 0,044 & 0,754 & Tidak Signifikan \\
KI $\left(\mathrm{X}_{3}\right)$ & 0,380 & 0,010 & Signifikan \\
\hline
\end{tabular}

Sumber: Lampiran Data diolah, 2019.

Persamaan regresi yang diperoleh dari pengujian tersebut adalah:

$$
\mathrm{Y}=0,200+0,439 \mathrm{X}_{1}+0,044 \mathrm{X}_{2}+0,380 \mathrm{X}_{3}+\mathrm{e}
$$

Dari persamaan regresi linier berganda tersebut dapat dijelaskan sebagai berikut:

1. Konstanta dalam persamaan regresi tersebut adalah 0,200. Artinya, jika CG $\left(\mathrm{X}_{1}\right)$, TATO $\left(\mathrm{X}_{2}\right)$, dan $\mathrm{KI}\left(\mathrm{X}_{3}\right)$ bernilai 0 ,maka ROA(Y) sebesar 0,200.

2. Nilai koefisien regresi variabel $C G\left(X_{1}\right)$ sebesar 0,439 . Artinya, jika terjadi peningkatan variabel CG $\left(X_{1}\right)$, maka nilai variabel ROA (Y) akan mengalami peningkatan sebesar 0,439.

3. Nilai koefisien regresi variabel TATO $\left(\mathrm{X}_{2}\right)$ sebesar 0,044. Artinya, jika terjadi peningkatan variabel TATO $\left(\mathrm{X}_{2}\right)$, maka nilai variabel ROA $(\mathrm{Y})$ tidak akan mengalami perubahan.

4. Nilai koefisien regresi variabel $\mathrm{KI}\left(\mathrm{X}_{3}\right)$ sebesar 0,380. Artinya, jika terjadi peningkatan variabel $\mathrm{KI}\left(\mathrm{X}_{3}\right)$, maka nilai variabel ROA (Y) akan mengalami kenaikan sebesar 0,380.

\section{Uji t}

Uji t digunakan untuk menguji signifikansi pengaruh variabel independen secara parsial terhadap variabel dependen. Hasil uji t sebagai berikut: 
Tabel 4. Hasil Uji t

\begin{tabular}{llll}
\hline \multicolumn{1}{c}{ Variabel } & Taraf Sig & Sig & \multicolumn{1}{c}{ Keterangan } \\
\hline CG $\left(\mathrm{X}_{1}\right)$ & 0,05 & 0,006 & Berpengaruh \\
TATO $\left(\mathrm{X}_{2}\right)$ & 0,05 & 0,754 & Tidak Berpengaruh \\
KI $\left(\mathrm{X}_{3}\right)$ & 0,05 & 0,010 & Berpengaruh \\
\hline
\end{tabular}

Sumber: Lampiran Data diolah, 2019.

Berdasarkan tabel tersebut dapat diketahui besar dari pengaruh masing-masing variabel independen terhadap variabel dependen sebagai berikut:

1. Pengaruh variabel CG $\left(\mathrm{X}_{1}\right)$ terhadap variabel ROA $(\mathrm{Y})$

Berdasarkan Tabel 4.4 dapat dilihat bahwaTingkat probabilitas $(\alpha)$ adalah 0,038 . Hal ini berarti CG berpengaruh terhadap ROA. Karena nilai probabilitas $<0,05$ maka terbukti kebenarannya $\left(\mathrm{H}_{1}\right.$ diterima).

2. Pengaruh variabel TATO $\left(\mathrm{X}_{2}\right)$ terhadap variabel ROA (Y)

Berdasarkan Tabel 4 dapat dilihat bahwaTingkat probabilitas $(\alpha)$ adalah 0,006 . Hal ini berarti TATO tidak berpengaruh signifikan terhadap ROA. Karena nilai probabilitas $>0,05$ maka tidak terbukti kebenarannya $\left(\mathrm{H}_{2}\right.$ ditolak).

3. Pengaruh variabel $\mathrm{KI}\left(\mathrm{X}_{3}\right)$ terhadap variabel ROA (Y)

Berdasarkan Tabel 4 dapat dilihat bahwaTingkat probabilitas $(\alpha)$ adalah 0,023. Hal ini berarti KI berpengaruh signifikan terhadap ROA. Karena nilai probabilitas $<0,05$ maka terbukti kebenarannya ( $\mathrm{H}_{3}$ diterima).

Berdasarkan hasil uji t dapat disimpulkan pada tabel rangkuman Hipotesis Penelitian berikut:

Tabel 4. Tabel Rangkuman Hipotesis Penelitian

\begin{tabular}{ll}
\hline \multicolumn{1}{c}{ Hipotesis } & Kesimpulan \\
\hline Pengaruh CG $\left(\mathrm{X}_{1}\right)-\mathrm{ROA}(\mathrm{Y})$ & $\mathrm{H}_{1}$ Diterima \\
Pengaruh TATO $\left(\mathrm{X}_{2}\right)-\mathrm{ROA}(\mathrm{Y})$ & $\mathrm{H}_{2}$ Ditolak \\
Pengaruh KI $\left(\mathrm{X}_{3}\right)-$ ROA $(\mathrm{Y})$ & $\mathrm{H}_{3}$ Diterima \\
\hline
\end{tabular}

Sumber: Lampiran Data diolah, 2019.

\section{Pembahasan \\ Pengaruh CG Terhadap ROA}

Hasil analisis regresi linier berganda pada Uji t terhadap hipotesis pertama (H1) dapat dilihat pada Tabel 4.9 bahwa CG berpengaruh terhadap ROA dengan melihat taraf signifikansinya yaitu sebesar 0,006. Artinya semakin tinggi CG maka akan meningkatkan $\mathrm{ROA}\left(\mathrm{H}_{1}\right.$ diterima).

Berdasarkan hasil analisis deskriptif menunjukkan bahwa nilai terendah variabel CG secara berturut-turut tahun 2015 - 2017 adalah PT Bakrie \& Brothers Tbk. Hal ini disebakan pihak perusahaan PT Bakrie \& Brothers Tbk mempunyai struktur tersendiri sehingga kurang memperhatikan tata kelola yang baik. PT Bakrie \& Brothers Tbk mempunyai nilai ROA bernilai negatif secara berturut-turut tahun 2015 - 2017 akibat tidak menerapkan tata kelola perusahaan yang baik. Nilai tertinggi variabel CG secara berturut-turut tahun 2015 - 2017 adalah PT Telekomunikasi Indonesia (Persero) Tbk. Hal ini disebakan pihak perusahaan PT Telekomunikasi Indonesia (Persero) Tbk sangat memperhatikan tata kelola yang baik karena perusahaan ini merupakan salah satu perusahaan BUMN di Indonesia. PT Telekomunikasi Indonesia (Persero) Tbk mempunyai nilai ROA bernilai positif secara berturut-turut tahun 2015 - 2017 hal ini merupakan dampak positif dari penerapan tata kelola perusahaan yang baik. Jadi dapat disimpulkan bahwa semakin baik penerapan tata kelola perusahaan yang maka akan meningkatkan kinerja keuangan perusahaan. Penerapan tata kelola perusahaan yang baik dapat menghindari tingkat fraud yang terjadi dalam suatu perusahaan.

Good Corporate Governance adalah suatu proses dan struktur yang digunakan oleh organ perusahaan guna memberikan nilai tambah pada perusahaan secara berkesinambungan dalam jangka panjang bagi pemegang saham, dengan tetap memperhatikan kepentingan stakehonders lainnya, berlandaskan peraturan perundang-undangan dan norma yang berlaku (Bukhori, 2012). Perusahaan yang menerapkan Good Corporate Governance memiliki kinerja keuangan yang baik, hal ini dikarenakan perusahaan telah menerapkan prinsip-prinsip Good Corporate Governance yaitu transparansi, akuntabilitas, kewajaran dan responsibility. Pengelolaan perusahaan yang baik membuat manajemen bekerja optimal sehingga tercapai kinerja keuangan yang optimal. 
Berdasarkan Signalling Theory memberikan Signal Good News Bagi Investor Karena Semakin tinggi nilai CG maka tingkat pengembalian investasi pemegang saham yang telah diinvestasikan kepada perusahaan juga akan tinggi. Maka jika nilai CG perusahaan itu tinggi perusahaan akan dengan mudah untuk mendapatkan investor guna untuk memperluas dan mengekspansi perusahaan untuk lebih maju dan berkembang lagi. Karena itu pengembalian rasio pengembalian investasi pemegang saham sangat penting artinya bagi pemegang saham sangat memperhatikan tingkat pengembalian investasi atas investasi yang ditanamkan terhadap perusahaan terutama bagi pemegang saham biasa.

\section{Pengaruh TATO Terhadap ROA}

Hasil analisis regresi linier berganda pada Uji t terhadap hipotesis kedua (H2) dapat dilihat pada Tabel 4.9 bahwa TATO tidak berpengaruh terhadap ROA dengan melihat taraf signifikansinya yaitu sebesar 0,754 , artinya semakin tinggi tidak akan memberikan perubahan terhadap ROA ( $\mathrm{H}_{2}$ ditolak).

Berdasarkan hasil analisis deskriptif menunjukkan bahwa nilai terendah variabel TATO yakni PT Bank Central Asia (Persero) Tbk pada tahun 2017. Namun nilai TATO PT Bank Central Asia (Persero) Tbk yang rendah tidak mempengaruhi kinerja keuangan perusahaan terbukti dengan nilai ROA yang positif pada tahun 2017. Nilai tertinggi variabel TATO pada tahun 2017 adalah PT Bukit Asam (Persero) Tbk. Nilai perputaran aktiva PT Bukit Asam (Persero) Tbk tidak berpengaruh terhadap nilai ROA sehingga kinerja keuangan perusahaan yang memiliki nilai TATO terendah dan tertinggi sama-sama menghasilkan nilai ROA yang tidak jauh berbeda.

Rasio Total Asset Turn Ove (TATO) adalah rasio yang digunakan untuk mengukur perputaran semua aktiva yang dimiliki perusahaan dan mengukur berapa jumlah penjualan yang diperoleh dari tiap rupiah aktiva (Kasmir, 2013). Semakin tinggi perputaran suatu aktiva perusahaan, maka akan semakin efektif perusahaan dalam mengelola asetnya dan semakin baik tingkat efesiensi penggunaan aktiva dalam menunjang penjualan. Perputaran aset yang meningkat akan dapat meningkatkan volume penjualan untuk mendapatkan laba yang maksimal maka semakin cepat tingkat perputaran aktiva maka semakin cepat peningkatan laba yang dihasilkan sehingga kinerja keuangan dapat bekerja secara optimal.

Berdasarkan Signalling Theory Semakin besar rasio profitabilitas memberikan Good News bagi investor, Karena Return on assets (TATO) yang positif menunjukkan bahwa dari total aktiva yang dipergunakan untuk beroperasi, perusahaan mampu memberikan laba bagi perusahaan. Sebaliknya apabila return on assets yang negatif menunjukkan bahwa dari total aktiva yang dipergunakan, perusahaan mendapatkan kerugian. Jadi jika suatu perusahaan mempunyai TATO yang tinggi maka perusahaan tersebut berpeluang besar dalam meningkatkan pertumbuhan. Tetapi jika total aktiva yang digunakan perusahaan tidak memberikan laba maka perusahaanakan mengalami kerugian dan akanmenghambat pertumbuhan. Maka ketika perusahaan memiliki nilai TATO yang tinggi akan menarik investor untuk menanamkan modalnya pada suatu perusahaan. Karena investor akan beranggapan bahwa perushaan yang memiliki nilai TATO yang tinggi perusahaan tersebut mampu memperoleh laba yang tinggi serta mampu meningkatkan pertumbuhan perusahaan. Dari laba yang tinggi perusahaan akan mamp membayarkan deviden yang tinggi dan tepat waktu kepada investor.

Hasil penelitian ini sejalan dengan penelitian sebelumnya yang dilakukan oleh Jestry J. Sambelay (2017) yang menyatakan bahwa TATO berpengaruh terhadap ROA. Jadi dapat disimpulkan bahwa TATO tidak berpengaruh terhadap ROA.

\section{Pengaruh KI Terhadap ROA}

Hasil analisis regresi linier berganda pada Uji t terhadap hipotesis ketiga (H3) dapat dilihat pada Tabel 4.9 bahwa KI berpengaruhterhadap ROAdengan melihat taraf signifikansinya yaitu sebesar 0,010. artinya semakin tinggi KI maka akan meningkatkan ROA $\left(\mathrm{H}_{3}\right.$ diterima).

Berdasarkan hasil analisis deskriptif menunjukkan bahwa nilai terendah variabel KI yakni PT Bank Negara Indonesia (Persero) Tbk pada tahun 2015. Nilai KI PT Bank Negara Indonesia (Persero) Tbk yang rendah mempengaruhi kinerja keuangan perusahaan terbukti dengan nilai ROA yang hanya 0,03 pada tahun 2015. Sedangkan nilai tertinggi variabel KI pada tahun 2015 adalah PT Semen Indonesia (Persero) Tbk yang mampu menunjukkan kinerja keuangan perusahaan yang lebih baik karena nilai ROA PT Semen Indonesia (Persero) Tbk sebesar 0,16. Kepemilikan Manajerial padaPT Semen Indonesia (Persero) Tbk pada tahun 2015 memberikan dampak yang positif terhadap kinerja kuangan karena perusahaan lebih giat untuk mencapai target yang telah ditetapkan.

Kepemilikan institusional adalah proporsi kepemilikan saham pada akhir tahun yang dimiliki oleh lembaga, seperti asuransi, bank atau institusi lain (Tarjo, 2008). Kepemilikan institusional yang memberikan proporsi yang sama antara kepentingan manajemen dan pemegang saham akan memperoleh manfaat langsung dari keputusan yang diambil. Semakin besar proporsi kepemilikan yang dipegang oleh manajemen perusahaan maka manajemen cenderung lebih giat untuk melakukan kinerja yang lebih baik. 
Hasil penelitian ini tidak sejalan dengan penelitian sebelumnya yang dilakukan oleh Denies Priatinah (2013) yang menyatakan bahwa KI berpengaruh terhadap ROA. Jadi dapat disimpulkan bahwa KI berpengaruh terhadap ROA.

\section{Pengaruh GC, TATO dan KI secara simultan terhadap ROA}

Hasil analisis regresi linier berganda pada Uji t terhadap hipotesis keempat (H4) dapat dilihat pada Tabel 4.9 bahwa GC, TATO dan KI berpengaruhterhadap ROA dengan melihat taraf signifikansinya yaitu sebesar 0,000. artinya semakin tinggi GC, TATO dan KI maka akan meningkatkan ROA ( $\mathrm{H}_{4}$ diterima).

Good Corporate Governance merupakan tata kelola perusahaan yang menjelaskan hubungan antara berbagai partisipan dalam perusahaan yang menentukan arah kinerja perusahaan. Kasmir (2013:185) Rasio total asset turn over merupakan rasio yang digunakan untuk mengukur perputaran semua aktiva yang dimiliki perusahaan dan mengukur berapa jumlah penjualan yang diperoleh daritiap rupiah aktiva. Brous \& Kini (1994) dalam Nuraeni (2010), menyatakan bahwa ketatnya pengawasan yang dilakukan oleh investor institusional sangat tergantung pada besarnya investasi yang dilakukan

\section{Simpulan dan saran}

Penelitian ini bertujuan untuk menguji pengaruh CG, TATO dan KI terhadap ROA. Berdasarkan sampel yang digunakan dalam penelitian ini yaitu 10 Perusahaan yang menjadi peserta Corporate Governance Perception Index (CGPI) tahun 2015-2017 dan ditentukan dengan menggunakan metode purposive sampling. Berdasarkan pembahasan pada bab IV, dapat diambil kesimpulan sebagai berikut bahwa hasil pengujian regresi berganda atas pengaruh CG terhadap ROA menunjukkan pengaruh positif signifikan. Ini membuktikan bahwa semakin besar CG akan meningkatkan ROA. Hasil pengujian regresi berganda atas pengaruh TATO terhadap ROA menunjukkan tidak berpengaruh signifikan. Ini membuktikan bahwa TATO yang tinggi tidak akan memberikan perubahan terhadap ROA. Hasil pengujian regresi berganda atas pengaruh KI terhadap ROA menunjukkan pengaruh yang positif dan signifikan. Ini membuktikan bahwa KI yang tinggi akan meningkatkan ROA. Hasil pengujian regresi berganda menunjukkan CG, TATO dan KI berpengaruh secara simultan terhadap ROA menunjukkan pengaruh yang positif dan signifikan. Ini membuktikan bahwa KI yang tinggi akan meningkatkan ROA.

Bagi peneliti selanjutnya, sebaiknya memperluas kriteria sampel pada perusahaan pertambangan dan perusahaan jasa yang terdaftar di Bursa Efek Indonesia (BEI). Bagi peneliti selanjutnya diharapkan melakukan penambahan sampel tahun penelititan yang lebih banyak agar dapat menggambarkan kondisi yang lebih konkrit misalnya 5 tahun

\section{Daftar Rujukan}

Anindtya, 2015. Pengaruh Mekanisme Corporate Governance terhadap Kinerja Keuangan Perusahaan Manufaktur yang Terdaftar di BEI dengan Agency Cost Sebagai Variabel Intervening). Fakultas Ekonomi dan Bisnis Universitas Sumater Utara. Medan.

Brigham dan Houston. 2010. Dasar-dasar Manajemen Keuangan Buku 1 (Edisi 11). Salemba Empat. Jakarta.

Carningsih. 2009. Pengaruh Good Corporate Governance terhadap Hubungan Antara Kinerja Keuangan dengan Nilai Perusahaan (Studi Kasus pada Perusahaan Properti dan Real Estate yang Terdaftar di Bursa Efek Indonesia). Skripsi. Universitas Gunadarma. Jakarta.

Damayanti, 2015. Pengaruh Good Corporate Governance terhadap Kinerja Keuangan (Studi Kasus Perusahaan Manufaktur yang Terdaftar di BEI Tahun 2011-2013). Fakultas Ekonomi dan Bisnis Universitas Diponegoro. Semarang

Darwis, Herman, 2009," Corporate Governance Terhadap Kinerja Perusahaan", Jurnal Keuangan dan Perbankan, Vol.13, No 13, Seprember 2009, Hal 418-430. Universitas Esa Unggul, Jakarta.

Diyah, Reni Retno m dan Denies Priantina. 2012. Pengaruh Good Corporate Governance dan Penungkapan Corporate Social Responsibility Perusahaan. Jurnal Nominal. Vol 1 No 2. Fakultas Ekonomi Universitas Negeri Yogyakarta, Yogyakarta. 
Ery Dan Ratna Widjayanti Dahniar Paramita .2014. Pengaruh Good Corporate Governance Terhadap Praktik Manajemen Laba Riil Pada Perusahaan Manufaktur. Jurnal Wiga Issn No 2088-0944 Vol. 4 No. 2, September 2014. Universitas Diponegoro, Semarang.

Fahmi, Irham. 2013. Analisis Laporan Keuangan: Alfabeta, Bandung.

Freshilia Welim dan Ch. Rustiti, 2014. "Pengaruh Kepemilikan Manajerial Dan Kepemilikan Institusional Terhadap Nilai Perusahaan (Studi Empiris Pada Perusahaan Perbankan yang Terdaftar di BEI)”. Jurnal. Fakultas Ekonomi Universitas Negeri, Yogyakarta.

Ghozali, Imam. 2013. Aplikasi Analisis Multivariate dengan Program SPSS. Edisi Ketujuh. Badan Penerbit Universitas Diponegoro. Semarang.

Gumanti, Tatang. 2011. Manajemen Investasi : Konsep, Teori, dan Aplikasi(Edisi 1): Mitra Wacana Media. Jakarta.

Herawati, Vinola. 2008. Peran Praktek Corporate Governance sebagai Moderating Variabel dari Pengaruh Earnings Management terhadap Nilai Perusahaan. Simposium Nasional Akuntansi XI. IAI.

Hermiyetti, 2013. Analisis Pengaruh Kepemilikan Manajerial, Kepemilikan Institusional, Kepemilikan Asing. Dan Komite Audit terhadap Kinerja Keuangan Perusahaan. Fakultas Ekonomi dan Bisnis Universitas Hasannudin. Makassar.

Indriantoro, Nur dan Supomo. 2014. Metodologi Penelitian Bisnis untuk Akuntansi \& Manajemen. BPFE. Sugiyono. Yogyakarta

Jogiyanto Hartono, 2013. Teori Portofolio dan Analisis Investasi, BPFE Yogyakarta, Edisi Kedelapan. Yogyakarta

Kadek Made Sadha. 2016. Pengaruh Struktur Kepemilikan Saham, Struktur Modal dan Profitabilitas pada Nilai Perusahaan. E-Jurnal Ekonomi dan Bisnis Universitas Udayana. Bali

Kasmir. 2013. Analisis Laporan Keuangan. Rajawali Pers. Jakarta.

Ramadhani, Ayu Suci dan Niki Lukviarman.2009. Hubungan Antara Good Corporate Governance dan Struktur Kepemilikan dengan Kinerja Keuangan (Studi kasus pada perusahaan yang listing di Bursa Efek Jakarta). Simposium Nasional Akuntansi VIII IAI.

Ratih, I Dewa Ayu dan Damayanthi, I Gusti Ayu Eka. 2016. Kepemilikan Manajerial dan Profitabilitas pada Nilai Perusahaan dengan Pengungkapan Tanggung jawab Sosial sebagai Variabel Pemoderasi. Fakultas Ekonomi dan Bisnis Universitas Udayana. Bali.

Widhianningrum, 2012. Pengaruh Mekanisme Good Corporate Governance terhadap Kinerja Keuangan selama Krisis Keuangan Tahun 2007-2009. Fakultas Ekonomi Universitas Muhammadiyah Yogyakarta. Yogyakarta.

Yasmine, 2013. Pengaruh Penerapan Good Corporate Governance terhadap Kinerja Keuangan dan Return Saham Perusahaan (Studi Pada Bumn Yang Terdaftar di Bursa Efek Indonesia Tahun 2009 - 2012. Fakultas Ekonomi dan Bisnis Universitas Universitas Andalas. Padang. 